\title{
Removal of Dissolved Silica from Industrial Waters using Inorganic Ion Exchangers
}

\author{
Koroush Sasan, Patrick V. Brady, James L. Krumhansl, ${ }^{+}$and Tina M. Nenoff * \\ Sandia National Laboratories, Albuquerque, NM 87185 USA \\ + Retired from Sandia National Laboratories \\ *Corresponding Author: tmnenof@sandia.gov
}

\begin{abstract}
Dissolved silica is ubiquitous in impaired waters, a fouling agent in desalination membranes, resistant to existing antiscalants, and difficult to remove from power plant feed waters, thereby inhibiting long term reuse of industrial water. Herein we report a systematic materials study of an inorganic anion exchanger, hydrotalcite $\left(\mathrm{HTC},\left(\mathrm{Mg}_{6} \mathrm{Al}_{2}(\mathrm{OH})_{16}\left(\mathrm{CO}_{3}\right)^{\bullet} 4 \mathrm{H}_{2} \mathrm{O}\right)\right)$, for the highly selective removal of silica from aqueous solutions. HTCs exist in two different forms: crystalline uncalcined and calcined $\left(550{ }^{\circ} \mathrm{C}\right)$ phases. Variables studied in ion-exchange studies include $\mathrm{pH}$, HTC concentration, duration and selectivity with competing anions. Results indicate calcined HTC effectively removes silicate anion from different waters including simulated concentrated cooling tower water (CCTW), and waters with high concentration of competing ions, such as $\mathrm{SO}_{4}{ }^{2-}$ and $\mathrm{Cl}^{-}$. The non-optimized HTC can be easily regenerated and recycled. Calcined HTC

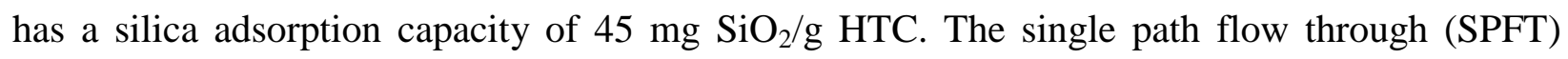
studies indicate that using $\sim 1.1 \mathrm{~g} / \mathrm{L}$ calcined HTC effectively removes $>90 \%$ of the dissolved silica from the CCTW. A pseudo-second order kinetic model was fit the experimental data of calcined HTC. Data is supported by Fourier transform infrared (FTIR), ThermogravimetricMass analyses (TGA-MS), Energy dispersive spectroscopy (EDS) and powder X-ray diffraction (XRD).
\end{abstract}

\section{Keywords:}

Dissolved silica, industrial waters recycle, ion exchange, hydrotalcite, recycle

(C) 2016. This manuscript version is made available under the Elsevier user license http://www.elsevier.com/open-access/userlicense/1.0/ 


\section{Introduction}

Fresh water scarcity is becoming a great global challenge. Water resources are limited and, hence, water treatment and recycling methods are vital alternatives for fresh water procurement in the upcoming decades.[1] These methods serve to remove harmful or problematic constituents from ground, surface and waste waters prior to their consumption, industrial utilization, or other uses.[2]

About half of all fresh water withdrawn daily in the US, 500 billion gal/day, is used by thermoelectric power generation plants. [3] The recovery cost for the impaired waters produced by the inland power generation sites is estimated to be 1.5-2 times the cost of freshwater, often because of the high cost of silica removal process. [4] A key solution to limited availability and high cost is reducing freshwater use and replacement of it with reclaimed waters, such as those from purified oilfield generated waters, municipal or agricultural waste waters, and subsurface brines.[4]

However, to be successful, dissolved silica and calcite forming mineral scale need to be removed. Antiscalant technology is well developed for calcite removal.[4] However, a low energy technology is needed for silica removal. The quality of the process affects the reuse and recycle of the reclaimed waters in individual operation. Currently, antiscaling technology enables $\sim 10$ recycles with calcite removal, however it is reduced down to 1-2 cycles due to silica buildup.[4]

Silica solubility depends on many factors such as $\mathrm{pH}$, temperature, pressure and ionic strength. The silica solubility is constant between $\mathrm{pH} 2$ and 8.5, but increases rapidly above $\mathrm{pH}$ 9. In the acidic-to-neutral $\mathrm{pH}$ range, silica exists as $\mathrm{H}_{4} \mathrm{SiO}_{4}$, whereas in basic solutions, it exists as $\mathrm{H}_{3} \mathrm{SiO}_{4}{ }^{-}$and $\mathrm{H}_{2} \mathrm{SiO}_{4}{ }^{2-}$ anionic species. [5, 6] Silica solubility is highly sensitive to temperature, increasing from $100-140 \mathrm{mg} / \mathrm{L}$ at ambient temperature, and then up to $300 \mathrm{mg} / \mathrm{L}$ at $70{ }^{\circ} \mathrm{C}$.[7]

Dissolved silica can be removed by a number of different methods including coagulation, nano-filtration (NF), reverse osmosis (RO), or precipitation.[8-10] Major limitations of NF and RO are fouling and high energy consumption.[11] The drawback of coagulation is that the process occurs at high $\mathrm{pH}$, resulting in increased costs due to $\mathrm{pH}$ adjustment.[8] Current technology like alumina precipitation may cause aluminosilicate 
scaling.[11] Additionally, these are different inorganic ion-exchange materials being used for metal ions separation from water.[12-14]

In an effort to develop highly selective silica ion-exchange materials that are robust, and both cost and energy efficient, we are exploring inorganic anion exchangers like hydrotalcites (HTC) as silica adsorbents.[15] HTCs are layered double-hydroxides with the general formula $\left[\mathrm{M}^{(\mathrm{II})}{ }_{1-\mathrm{x}} \mathrm{M}^{(\mathrm{III})}{ }_{\mathrm{X}}(\mathrm{OH})_{2}\right]^{\mathrm{x+}}[\mathrm{A}] \cdot \mathrm{mH}_{2} \mathrm{O}$ where $\mathrm{M}^{(\mathrm{II})}=\mathrm{Mg}^{2+}, \mathrm{Mn}^{2+}, \mathrm{Fe}^{2+}$, $\mathrm{Co}^{2+}, \mathrm{Ni}^{2+}$, and $\mathrm{Zn}^{2+} ; \mathrm{M}^{(\mathrm{III})}=\mathrm{Al}^{3+}, \mathrm{Cr}^{3+}, \mathrm{Mn}^{3+}, \mathrm{Fe}^{3+}, \mathrm{Co}^{3+}$, and $\mathrm{Ga}^{3+}$; and $\mathrm{A}=\mathrm{Cl}^{-}, \mathrm{Br}^{-}, \mathrm{I}^{-}$, $\mathrm{NO}_{3}{ }^{-}, \mathrm{CO}_{3}{ }^{2-}, \mathrm{SO}_{4}{ }^{2-}$, silicate-, polyoxometalate-, and/or organic anions.[16, 17] HTC is made up of positively charged $\left[\mathrm{M}^{(\mathrm{II})} / \mathrm{M}^{(\mathrm{III})} / \mathrm{OH}\right]$ layers, which have a substantial anion exchange capacity of $\sim 3$ meq/g.[15, 18] Our previous work showed the ability of HTC as a highly selective anion exchange material in a low energy, brackish water, desalination process.[15]

This work directly relates to needs identified in the Energy-Water Nexus by the US Department of Energy, as an important research area.[19] Herein, the use of HTC $\left(\mathrm{Mg}_{6} \mathrm{Al}_{2}(\mathrm{OH})_{16}\left(\mathrm{CO}_{3}\right) \cdot 4 \mathrm{H}_{2} \mathrm{O}\right)$ as an ion-exchange material for the selective ion-exchange and capture of silica ions is described in detail. Materials studies of the HTC, the mechanism of silica ion capture, and the efficiency of HTCs for silica removal from simulated industrial waters are explored. Detailed HTC synthesis, structural characterization and silica removal measurements are presented at various $\mathrm{pH}$ readings and concentrations levels. Composition studies with Zn-HTC $\left.\left(\mathrm{Zn}_{0.65} \mathrm{Al}_{\mathrm{o.35}}(\mathrm{OH})_{2}\right)\left(\mathrm{CO}_{3}\right)_{0.167}\left(\mathrm{H}_{2} \mathrm{O}\right)_{0.499}\right)$ analog are presented. Furthermore, the adsorption kinetics of the silica removal is determined and discussed.

\section{Experimental}

Commercial HTC $\left(\mathrm{Mg}_{6} \mathrm{Al}_{2}(\mathrm{OH})_{16}\left(\mathrm{CO}_{3}\right) \bullet 4 \mathrm{H}_{2} \mathrm{O}\right)$ from Sigma-Aldrich was used in this study. XRD, FTIR, TGA-MS and SEM-EDS were used to confirm the composition of HTC. [15, 20] $15 \mathrm{~g}$ batches of HTC were calcined in air at $550{ }^{\circ} \mathrm{C}$ for $3 \mathrm{~h}$.[20] Synthetic industrial water (Concentrated Cooling Tower water, CCTW) was made by salt addition to DI water with the following concentrations (mmol/L): $0.41 \mathrm{MgCl}_{2}+0.05 \mathrm{Na}_{2} \mathrm{SO}_{4}+$ $0.62 \mathrm{NaHCO}_{3}+1.0 \mathrm{CaCl}_{2}+41.0 \mathrm{NaCl}+0.833 \mathrm{SiO}_{2}$. 
For the batch silica removal reactions, typically $25-125 \mathrm{mg}$ of HTC was added to 50 $\mathrm{mL}$ of the synthetic CCTW in $50 \mathrm{~mL}$ tubes, and the tube placed on a shaker table for 12 hours at room temperature. After shaking, the slurry was centrifuged, and the $\mathrm{pH}$ and silica concentration of supernatant were determined. The percentage of silica removal was calculated based on the mass of silica removed by HTC to the initial mass of silica in water. The silica adsorption capacity is defined as the mass of silica removed from solution to the mass calcined HTC was used for silica removal.

Silica adsorption by HTC as a function of time was studied. In these experiments, 75 $\mathrm{mg}$ of calcined HTC was added to $50 \mathrm{~mL}$ of synthetic CCTW in a $50 \mathrm{~mL}$ tube; the tube was placed on shaker for a given time, up to $250 \mathrm{~min}$. The resultant slurry was centrifuged, and silica concentration of supernatant was determined by optical spectrophotometry (see below).

Testing of competitive selectivity of the HTC occurred in three experimental set-ups. (1) Effect of pH: $25-125 \mathrm{mg}$ of calcined HTC was added to $50 \mathrm{~mL}$ of the synthetic CCTW at $\mathrm{pH}$ 4-9 (the initial $\mathrm{pH}$ was adjusted by addition of $0.1 \mathrm{~mol} / \mathrm{L} \mathrm{HCl}$ or $\mathrm{NaOH}$ ). Solution was placed on a shaker table for 12 hours at room temperature. Then the slurry was centrifuged and the $\mathrm{pH}$ of solution were measured. (2) Effect of competing anions: Binary-solute systems of $\mathrm{SiO}_{2} / \mathrm{SO}_{4}{ }^{2-}$ and $\mathrm{SiO}_{2} / \mathrm{Cl}^{-}\left(\mathrm{NaCl}\right.$ and $\mathrm{Na}_{2} \mathrm{SO}_{4}$ as sulfate and chloride sources), respectively, were mixed with the initial $\mathrm{SiO}_{2}$ concentration $(50 \mathrm{mg} / \mathrm{L})$ and the calcined HTC (125 mg). (3) Effect of HTC regeneration: The spent HTC was dried overnight in air at $60{ }^{\circ} \mathrm{C}$, and heated at $550{ }^{\circ} \mathrm{C}$ for $2 \mathrm{~h}$. This process allowed for the regeneration of the crystalline HTC after each subsequent calcination for the silica removal process. (4) Effect of varying HTC composition on silica removal: Zn-HTC $\left(\mathrm{Zn}_{0.65} \mathrm{Al}_{\mathrm{O} .35}(\mathrm{OH})_{2}\right)\left(\mathrm{CO}_{3}\right)_{0.167} \cdot\left(\mathrm{H}_{2} \mathrm{O}\right)_{0.499}$ was synthesized using a method previously reported.[21, 22] Typically, a solution of $0.04 \mathrm{~mol} \mathrm{Zn}\left(\mathrm{NO}_{3}\right)_{2}$ and $0.02 \mathrm{~mol} \mathrm{Al}\left(\mathrm{NO}_{3}\right)_{3}$ was mixed in $100 \mathrm{~mL}$ of distilled water and added to a second solution containing $0.15 \mathrm{~mol}$ of $\mathrm{NaOH}$ and $0.03 \mathrm{~mol} \mathrm{Na}_{2} \mathrm{CO}_{3}$ in $100 \mathrm{~mL}$ of water at room temperature. The mixture was stirred for $24 \mathrm{~h}$. Then the precipitate product was filtrated, washed few times with distilled water and dried at $80^{\circ} \mathrm{C}$ for $24 \mathrm{~h}$. Then, $\mathrm{Zn}-\mathrm{HTC}$ was calcined in air at $300^{\circ} \mathrm{C}$ for 2h. Silica adsorption by Zn-HTC was also studied. In these experiments, 25-125 mg of calcined Zn-HTC was added to $50 \mathrm{~mL}$ of the synthetic CCTW and the solution was 
placed on a shaker table for 12 hours at room temperature. Then the resultant slurry was centrifuged and the silica concentration of the supernatant were determined.

A modified single path flow through (SPFT) measurement was done using synthetic CCTW and calcined HTC.[15] CCTW was pumped through columns containing 100-200 $\mathrm{mg}$ of calcined HTC at a flow rate of $0.15 \mathrm{~mL} \mathrm{~min}^{-1}$. Treated CCTW effluent was periodically collected and the silica concentration and $\mathrm{pH}$ determined. The steady state volume of fluid in the reactor was $\sim 1 \mathrm{~mL}$, which points to an average fluid residence time of $\sim 7$ minutes.

Fourier transform infrared (FTIR) spectroscopy of HTC was collected using a PerkinElmer FTIR Spectrometer GX. Spectra were collected in the mid-IR range of 400 to 4000 $\mathrm{cm}^{-1}$, with a resolution of $2 \mathrm{~cm}^{-1}$. Thermogravimetric-Mass analyses (TGA-MS) were carried out in air using a TA instruments STD 2960 with mass spectrometer GSD 320 from Pfeiffer Vacuum. Heating profile was $5{ }^{\circ} \mathrm{C} \mathrm{min}^{-1}$ liner ramp from a room temperature to $550{ }^{\circ} \mathrm{C}$. Powder X-ray diffraction (XRD) patterns were recorded at room temperature on a Siemens Kirstalloflex D500 diffractometer $(\mathrm{Cu}$ K $\alpha$ radiation) 40 kv, 30 $\mathrm{mA} ; 2 \theta=5-60^{\circ}, 0.05^{\circ}$ step size, and $3 \mathrm{~s}$ count time. Energy dispersive spectroscopy (EDS) and scanning electron microscopy (SEM) data were collected on a JEOL JMS-6300V scanning electron microscope with the LINK GEM light-window energy dispersive spectrometer. A Micromeritics ASAP 2020 instrument was used to collected surface area analysis at $-196{ }^{\circ} \mathrm{C}$ in $\mathrm{N}_{2}$. Prior to analysis, the samples were degassed at $120{ }^{\circ} \mathrm{C}$ for 12 hours. The surface area was measured by the Brunauer-Emmet-Teller (BET) method, assuming a cross-sectional area of $0.162 \mathrm{~nm}^{2}$ for the $\mathrm{N}_{2}$ molecule. The silica concentration was measured by using the optical Hach method 8185 and DR/2400 spectrophotometer. The $\mathrm{pH}$ of the solution was measured with a Thermo Scientific $\mathrm{pH}$ meter.

\section{Results and Discussion}

\subsection{HTC Characterizations}

The silica removal study was carried out using HTC and simulated CCTW containing 50 $\mathrm{mg} / \mathrm{L}$ of silica. A variety of materials characterization techniques were used to gain an 
understanding of both the HTC/silica post adsorption and the mechanism of silica adsorption by HTC.

The surface area of calcined HTC was $\sim 138 \mathrm{~m}^{2} / \mathrm{g}$, whereas the uncalcined HTC was $\sim 12 \mathrm{~m}^{2} / \mathrm{g}$. (See SI; Figure S1) The higher surface area for calcined HTC can be a result of the decrease in HTC crystal size caused by thermal treatment as shown in related studies.[23, 24] This decrease in crystal size is supported by the broadening of XRD peaks for calcined HTC [24] (Figure 1). The XRD pattern matches indicates that the HTC structure collapsed and formed mixed oxide during heat treatment.[25]

$\mathrm{Mg}_{6} \mathrm{Al}_{2}(\mathrm{OH})_{16}\left(\mathrm{CO}_{3}\right) \cdot 4 \mathrm{H}_{2} \mathrm{O} \longrightarrow 5 \mathrm{MgO} \cdot \mathrm{MgAl}_{2} \mathrm{O}_{4}+\mathrm{CO}_{2}+\mathrm{H}_{2} \mathrm{O}$

The calcined HTC is reconstructed to its original structure when mixed in water containing anions of the correct size, charge and/or size in the interlayer of the recrystallized HTC.[26, 27]

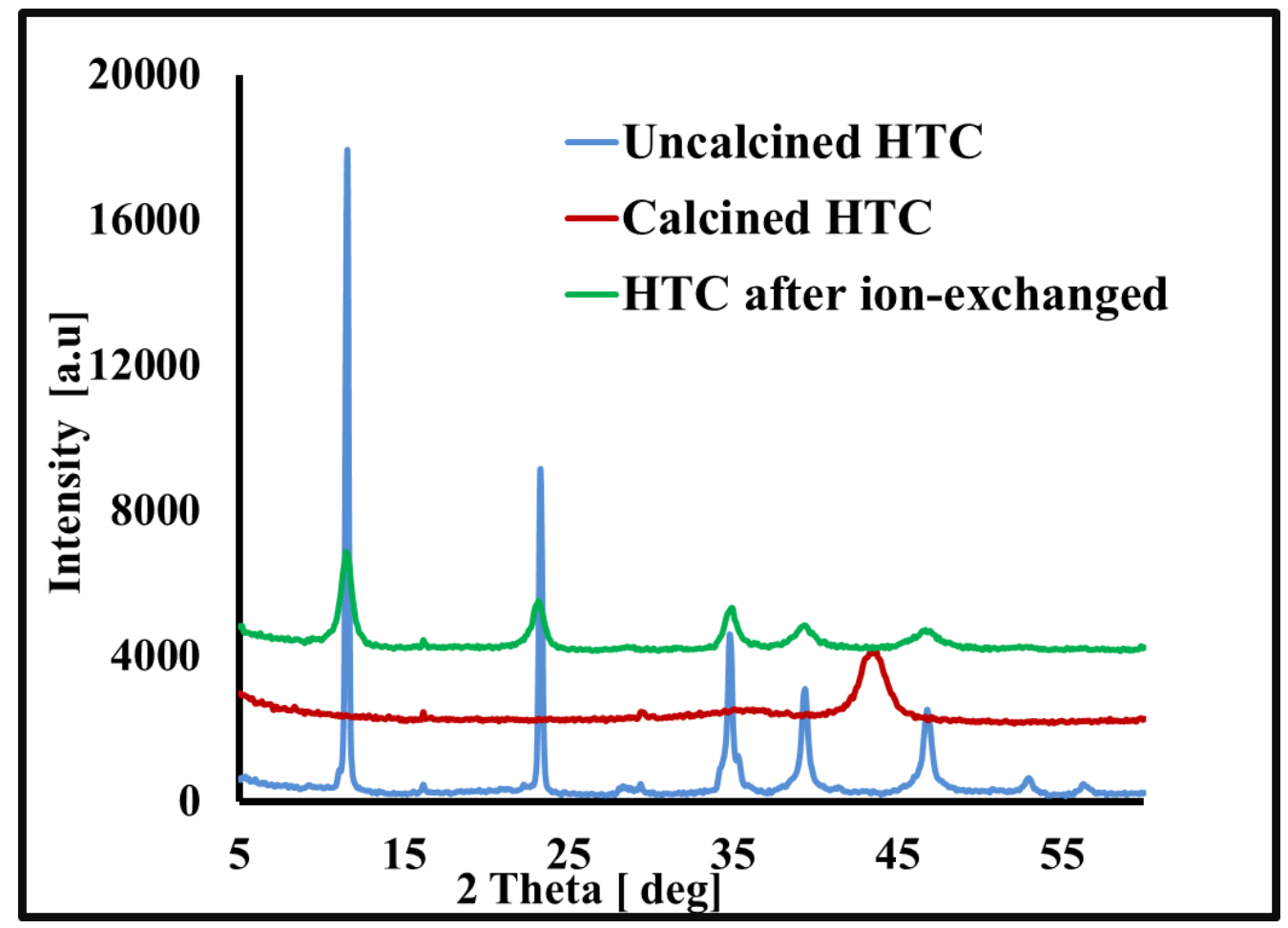

Figure 1. XRD patterns of uncalcined HTC (blue), calcined $\mathrm{HTC}$ after heating in air at $550{ }^{\circ} \mathrm{C}$ (red) and regenerated HTC after mixing with CCTW (green). 
TGA analysis of uncalcined HTC shows that thermal decomposition of HTC takes place at two distinct steps (See SI; Figure S2). In Step I, the initial mass loss begins at room temperature and ends at $\sim 250{ }^{\circ} \mathrm{C}$, with $\sim 14 \%$ mass lost. This corresponds to the loss of water molecules located between the $\mathrm{Mg} / \mathrm{Al} / \mathrm{OH}$ layers.[28] In Step II, the additional mass loss of $\sim 31 \%$ and occurs between $\sim 250{ }^{\circ} \mathrm{C}$ and $510{ }^{\circ} \mathrm{C}$. Concurrent TGA-MS analysis indicates an initial mass loss of $\sim 7 \%$ is associated with carbonate anions, followed by gradual mass loss of $\sim 24 \%$ corresponding to loss of interlayer water molecules (condensation of $\mathrm{OH}$ groups from the $\mathrm{Mg} / \mathrm{Al} / \mathrm{OH}$ layers).[28] The corresponding XRD shows a broadening of XRD peaks, indicating decrease of the crystal size of HTC. The transition in the structural formulas listed below:

Step I, $\left(\mathrm{Mg}_{6} \mathrm{Al}_{2}(\mathrm{OH})_{16}\left(\mathrm{CO}_{3}\right) \bullet 4 \mathrm{H}_{2} \mathrm{O}\right)-4 \mathrm{H}_{2} \mathrm{O} \longrightarrow \quad\left(\mathrm{Mg}_{6} \mathrm{Al}_{2}(\mathrm{OH})_{16}\left(\mathrm{CO}_{3}\right)\right)$

(Calc. Wt. Loss $=11.9 \%)$

Step II, $\left(\mathrm{Mg}_{6} \mathrm{Al}_{2}(\mathrm{OH})_{16}\left(\mathrm{CO}_{3}\right)\right)-\mathrm{CO}_{2}-8 \mathrm{H}_{2} \mathrm{O} \longrightarrow 5 \mathrm{MgO} \cdot \mathrm{MgAl}_{2} \mathrm{O}_{4}$

(Calc. Wt. Loss $=31.2 \%)$

Direct comparison of the FTIR data for uncalcined and calcined HTC clearly shows the decrease in intensity of the infrared peaks from the calcined material, which confirms the decarbonisation and dihydroxylation of the HTC during the calcination process (Figure 2). In the uncalcined HTC data, a peak at $3400 \mathrm{~cm}^{-1}$ is attributed to the metal hydroxide and water adsorbed into the $\mathrm{Mg} / \mathrm{Al} / \mathrm{OH}$ layers.[29-31] The peak at $1634 \mathrm{~cm}^{-1}$ correspond to water bending mode and the peak at $1434 \mathrm{~cm}^{-1}$ is attributed to a carbonate of uncalcined HTC, as previously reported.[29-32] After calcination, the peak at $3400 \mathrm{~cm}^{-1}$ and $1634 \mathrm{~cm}^{-1}$ have almost disappeared, which is the indicative of dehydration during thermal treatment. Also, the intensity of a carbonate peak at $1434 \mathrm{~cm}^{-1}$ has significantly decreased which indicates the carbonate mostly was removed during calcination. 


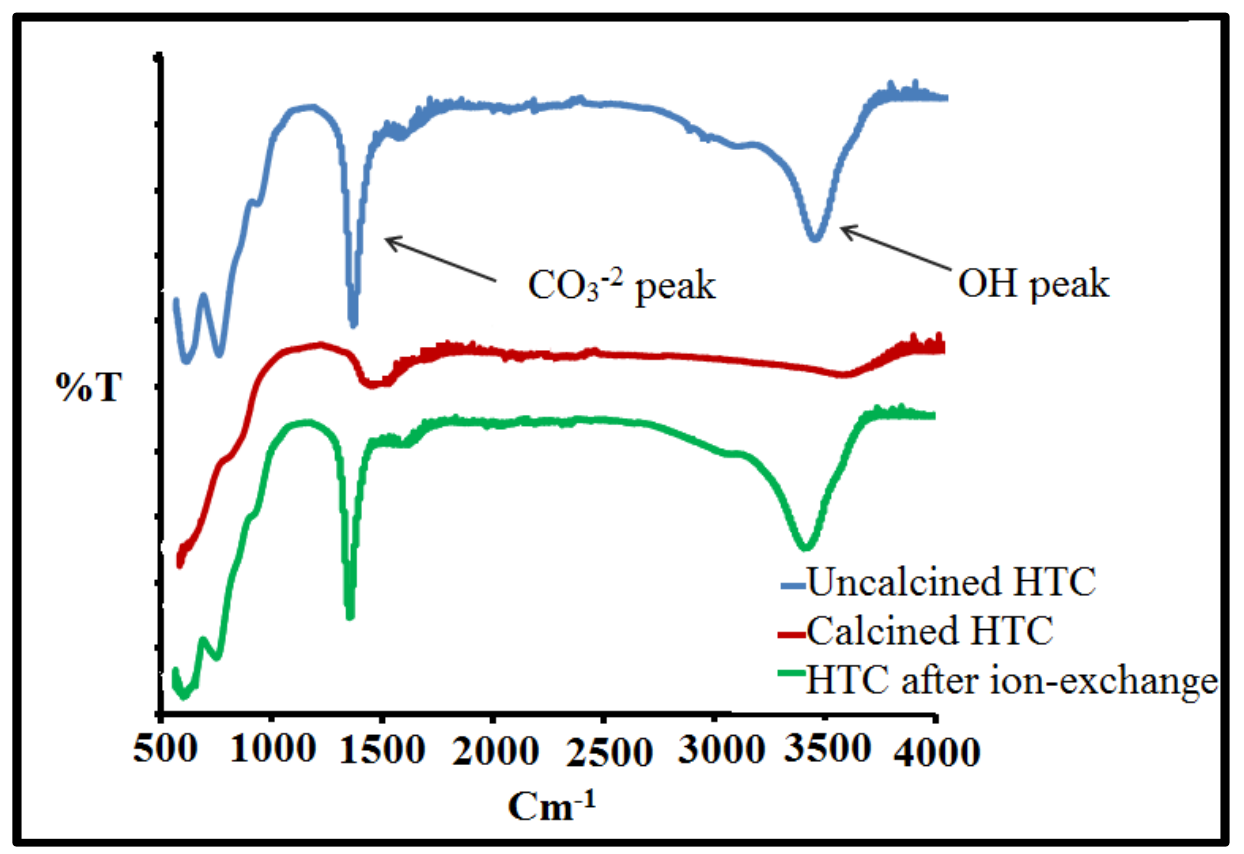

Figure 2. FTIR spectra of uncalcined HTC, calcined HTC and HTC after ion-exchanged (calcined HTC after water treatment). A peak at $3400 \mathrm{~cm}^{-1}$ is the absorption spectra of -OH, and peaks at $1634 \mathrm{~cm}^{-1}$ and $1434 \mathrm{~cm}^{-1}$ correspond to a water bending mode and a carbonate group, respectively.

\subsection{Mechanism of silica removal}

Two different adsorption mechanisms can be used to describe the silica removal by HTC. The first process is direct ion-exchange with the interlayer anions of uncalcined HTC.[23] The second process involves the silica removal by calcined HTC, in which the collapsed material is dispersed into an aqueous solution containing silicate ions, and the HTC structure recrystallizes around the silicate ion.[23, 33, 34]

To understand which ion-exchange mechanism favors silica removal, both uncalcined HTC and calcined HTC were individually treated with CCTW (see Figure 3). Using either 75 or $125 \mathrm{mg}$ of calcined HTC resulted in more than $90 \%$ silica removal. By contrast, using $125 \mathrm{mg}$ of crystalline HTC resulted in only $10 \%$ silica removal. This demonstrates that the calcined HTC is a more effective silica removal material than uncalcined HTC. The silica adsorption capacity of calcined HTC is approximated to be

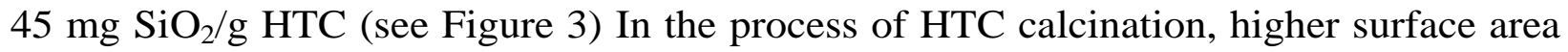
is generated available for ion-exchange which results in higher silica removal on calcined HTC $\left(\sim 138 \mathrm{~m}^{2} / \mathrm{g}\right)$ compared to uncalcined $\left(\sim 12 \mathrm{~m}^{2} / \mathrm{g}\right)$. 


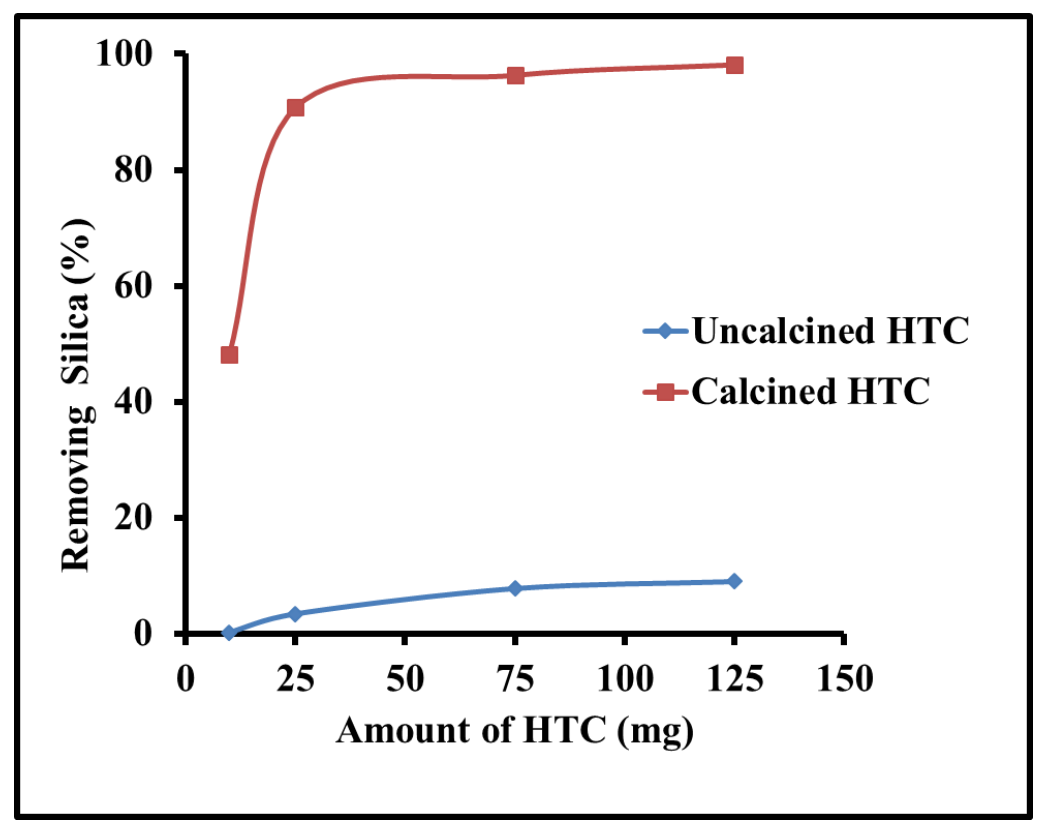

Figure 3. Silica removal from CCTW by uncalcined HTC and calcined HTC $\left(\mathrm{pH}=7.0,25{ }^{\circ} \mathrm{C}\right.$, $50 \mathrm{mg} / \mathrm{L} \mathrm{SiO}_{2}$ ).

Figure 4 shows data from time-dependent silica removal studies. Silica removal starts at a rapid rate in the first 25 minutes. However, the adsorption rate slows and reaches equilibrium early ( $\sim 50$ mins) and is completed by 200 minutes. 


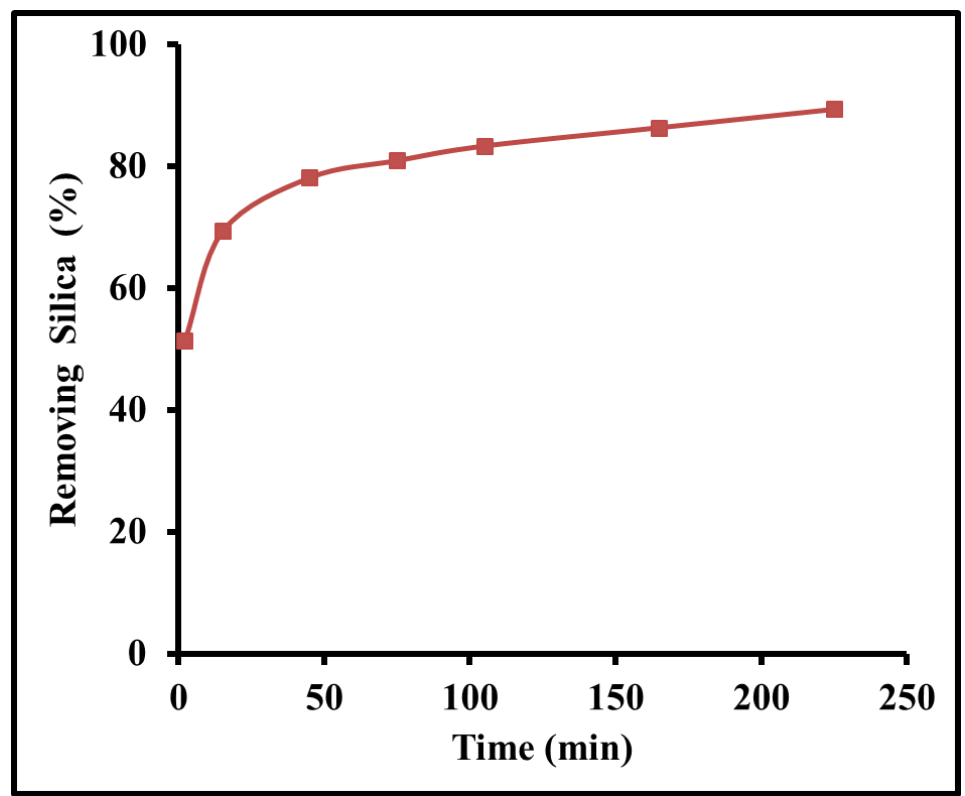

Figure 4.Time-dependent silica removal during ion-exchange by calcined HTC (75 mg HTC, pH $=7.5,50 \mathrm{mg} / \mathrm{L} \mathrm{SiO} 2$ ).

\subsection{Single Path Flow Through (SPFT) measurement}

The SPFT test was used to measure HTC uptake of silica under more rapid flow-through conditions and to provide a measure of uptake capacity.[15] Recall that the fluid residence time in the SPFT is $\sim 7$ minutes; batch reaction times were carried out to 25 hours. Greater than $>90 \%$ silica removal occurs rapidly and persists until $\sim 4$ hours, at which point the rate of silica removal declines (see Figure 5). The SPFT results point to a

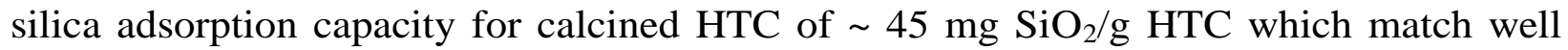
with adsorption capacity measurement from the batch testing (see Figure 3 ). 


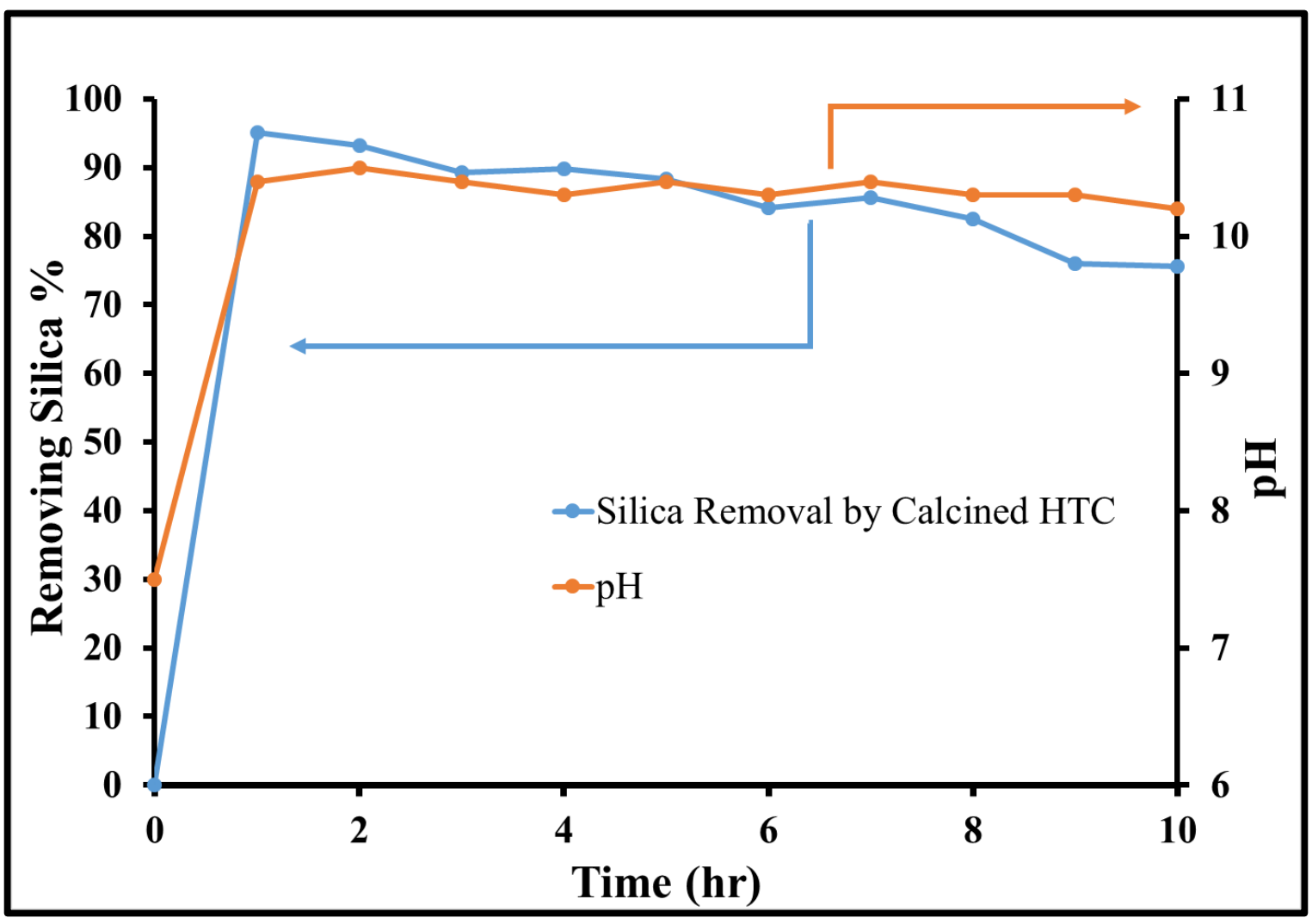

Figure 5. SPFT: Silica removal from CCTW $\left(\mathrm{pH}=7.0,25^{\circ} \mathrm{C}, 50 \mathrm{mg} / \mathrm{L} \mathrm{SiO}_{2}\right), 200 \mathrm{mg}$ calcined HTC with a flow rate of $0.15 \mathrm{~mL} \mathrm{~min}^{-1}$. Arrows included to clarify axes.

\subsection{Effect of pH on silica removal by calcined HTC}

Changing the initial $\mathrm{pH}$ from 4 to 9 results in no significant effect on the silica removal performance by calcined HTC. Silica exists in the neutral form $\left(\mathrm{H}_{4} \mathrm{SiO}_{4}\right)$ in the initial $\mathrm{pH}$ range (4 - 9), and is not available for ion-exchange.[35] As the $\mathrm{pH}$ of the solution rapidly increase to $\geq 9.8$ after the addition calcined HTC to the CCTW solution; this is concurrent with the formation of $\mathrm{H}_{3} \mathrm{SiO}_{4}{ }^{-}$silica ions in solution. 


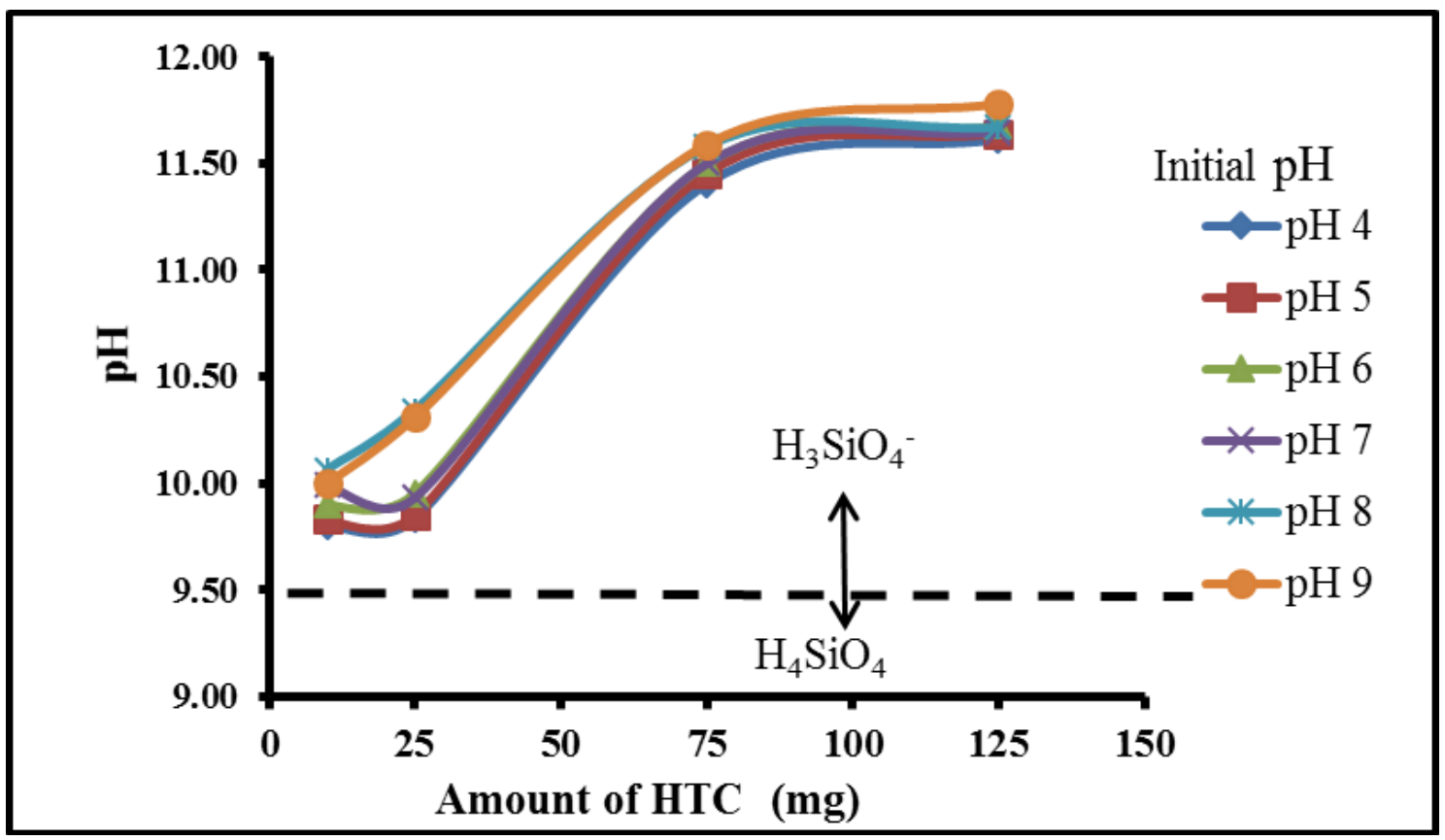

Figure 6. The $\mathrm{pH}$ of CCTW solutions after treatment with calcined HTC. At $\mathrm{pH}>9.5$ the silica exists as $\mathrm{a}_{3} \mathrm{SiO}_{4}{ }^{-}$anion.

Changing the solution $\mathrm{pH}$ and adsorption silica ions by calcined HTC occurs as follows:

(1) $\mathrm{OH}^{-}$ions are generated during reconstruction of HTC from magnesium and aluminum mixed oxides to the original crystalline structure (Eq.2). Concurrently, all available ions $\left(\mathrm{Cl}^{-}, \mathrm{HCO}_{3}{ }^{-}, \mathrm{CO}_{3}{ }^{-2}\right.$, etc.) are adsorbed into the HTC interlayer (see Eq.2). [36]

$5 \mathrm{MgO} \cdot \mathrm{MgAl}_{2} \mathrm{O}_{4}+13 \mathrm{H}_{2} \mathrm{O}+\mathrm{X}\left(\mathrm{X}=\mathrm{Cl}^{-}, \mathrm{HCO}_{3}{ }^{-}, \mathrm{CO}_{3}{ }^{-2}\right.$, etc. $) \longrightarrow$

$\mathrm{Mg}_{6} \mathrm{Al}_{2}(\mathrm{OH})_{16} \mathrm{X} \cdot 4 \mathrm{H}_{2} \mathrm{O}+2 \mathrm{OH}^{-}$

(2) As the $\mathrm{pH}$ rises to greater than 9.5, most of the silica is in the form of $\mathrm{H}_{3} \mathrm{SiO}_{4}{ }^{-}$ions, (Figure 6) and thus is available for ion-exchange by the HTC.[6, 35] Remaining oxides crystallize to HTC with the adsorbed silicate anions in the interlayers (see Eq. 3).

$5 \mathrm{MgO} \cdot \mathrm{MgAl}_{2} \mathrm{O}_{4}+13 \mathrm{H}_{2} \mathrm{O}+\mathrm{H}_{3} \mathrm{SiO}_{4}^{-} \longrightarrow \mathrm{Mg}_{6} \mathrm{Al}_{2}(\mathrm{OH})_{16}\left(\mathrm{H}_{3} \mathrm{SiO}_{4}\right)_{\times} \bullet 4 \mathrm{HO}_{2}+2 \mathrm{OH}^{-}$ 
XRD and FTIR analyses (Figures 1 and 2) confirm the recrystallization of HTC after exposure to CCTW. SEM-EDS spectroscopy confirms the presence of both silica and chlorine in the regenerated HTC phase (Figure 7).

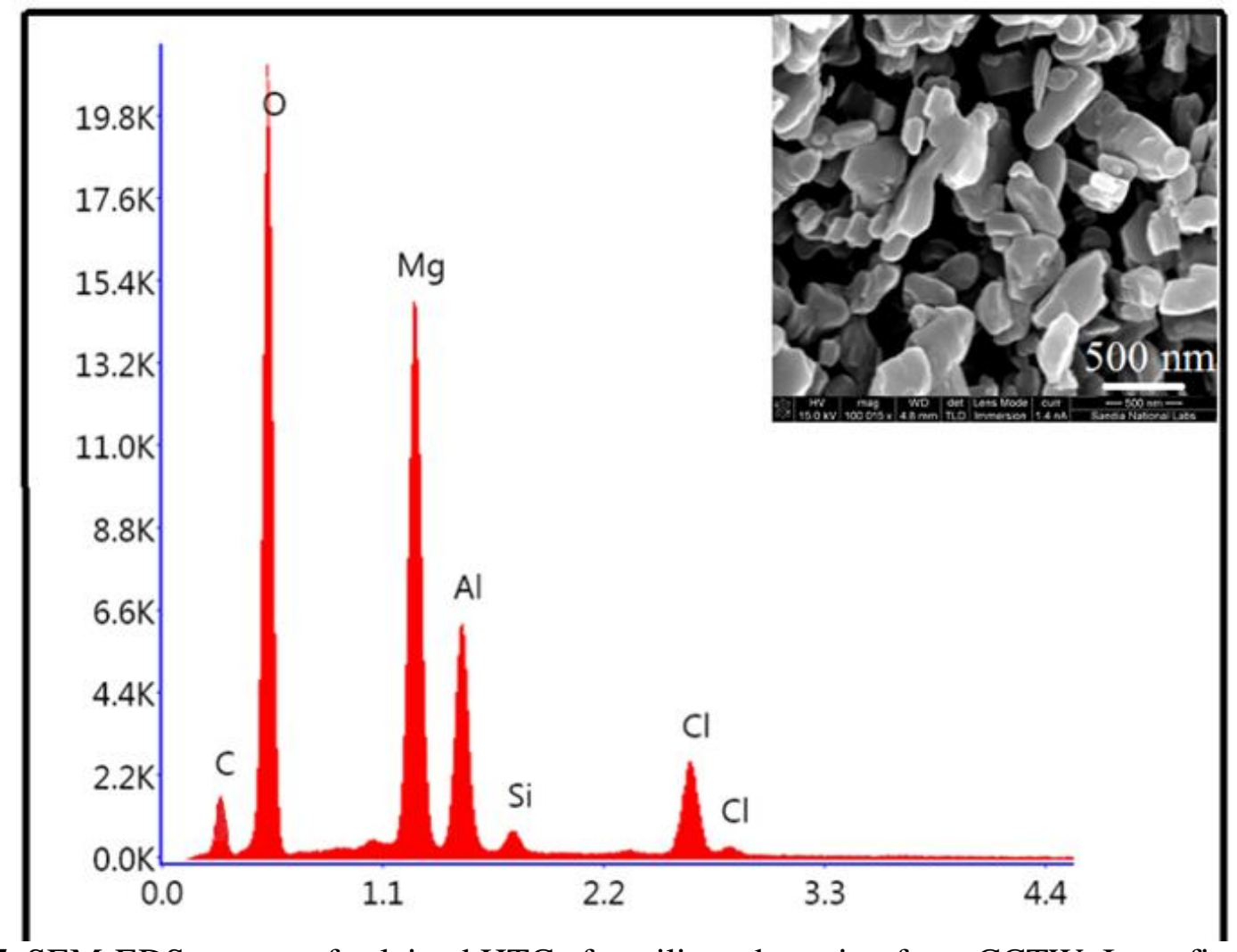

Figure 7. SEM-EDS pattern of calcined HTC after silica adsorption from CCTW. It confirms the presence of silica and chlorine.

\subsection{Effect of competing ions on silica removal by calcined HTC}

Cooling tower water contains ions such as sulfate and chloride which might compete with silica for HTC adsorption sites.[37] This study focuses on the ability of HTC to adsorb silica in the presence of competing anions. Binary solute systems of $\mathrm{SiO}_{2} / \mathrm{SO}_{4}{ }^{2-}$ and $\mathrm{SiO}_{2} / \mathrm{Cl}^{-}$, respectively, were measured with calcined HTC. Table 1 . shows that at silicate/chloride $=1 / 20, \sim 98 \%$ of dissolved silica was removed suggesting a strong preference of HTC for silicate over chloride. Similarly, at silicate/sulfate $=1 / 20, \sim 95 \%$ of the silicate was removed. The slightly lower silica removal in the presence of sulfate may be a due to the higher charge of $\mathrm{SO}_{4}{ }^{2-}$ over $\mathrm{Cl}^{-}$.[15] Overall, the competing ions studies 
indicate that silica adsorption by calcined HTC is selective in the presence of competing ions such as $\mathrm{Cl}^{-}$and $\mathrm{SO}_{4}{ }^{2-}$.

Table 1. Percent silica removal by HTC in presence of varying concentration of chloride and sulfate ions (initial silica concentration $50 \mathrm{mg} / \mathrm{L}, 50 \mathrm{~mL}, 125 \mathrm{mg} \mathrm{HTC}$ ).

\begin{tabular}{llll}
\hline $\begin{array}{l}\text { Sample ratio } \\
\text { Silica: } \\
\text { Chloride }\end{array}$ & $\begin{array}{l}\text { Removed } \\
\text { silica (\%) }\end{array}$ & $\begin{array}{l}\text { Sample ratio } \\
\text { Silica: Sulfate }\end{array}$ & $\begin{array}{l}\text { Removed } \\
\text { Silica (\%) }\end{array}$ \\
\hline $1: 1$ & $99.0 \%$ & $1: 1$ & $99.0 \%$ \\
$1: 5$ & $98.8 \%$ & $1: 5$ & $97.0 \%$ \\
$1: 10$ & $98.5 \%$ & $1: 10$ & $95.8 \%$ \\
$1: 15$ & $97.9 \%$ & $1: 15$ & $95.2 \%$ \\
$1: 20$ & $97.6 \%$ & $1: 20$ & $94.8 \%$ \\
\hline
\end{tabular}

\subsection{Regeneration of HTC}

Thermal regeneration of spent $\mathrm{HTC}$ was performed at $550{ }^{\circ} \mathrm{C}$. The HTC after each subsequent calcination was used again for the removal of silicate anion from CCTW. The XRD patterns from four subsequent regeneration cycles show that the HTC peak intensities decreased after each calcination and reconstruction cycle (see Figure 8). 


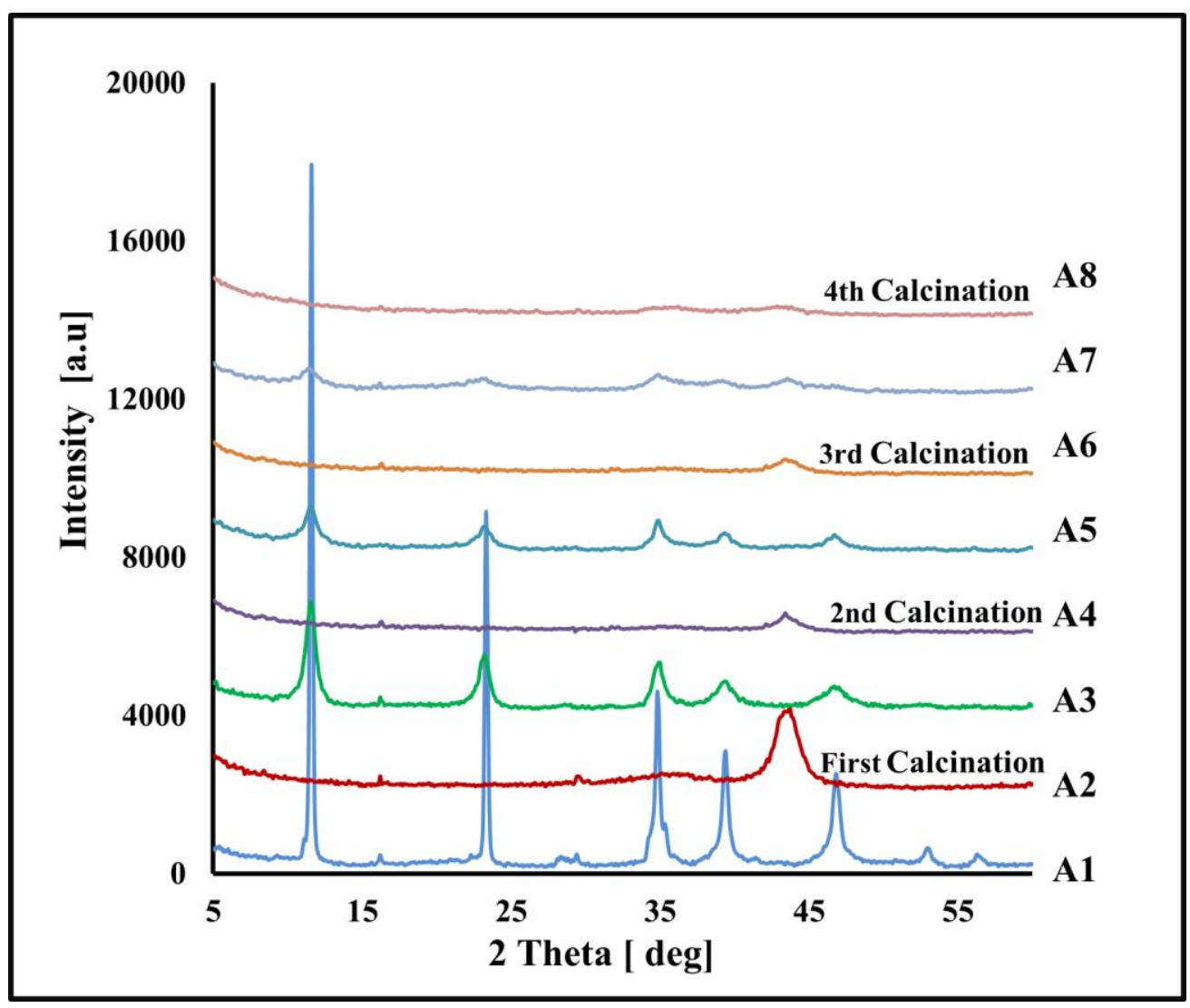

Figure 8. XRD patterns of HTC during regeneration cycles with CCTW. A1 is the original HTC sample. Cycle 1 (A2/A3) is regeneration calcination and recrystallization of the HTC. Cycles 2 (A4/A5), 3 (A6/A7), and 4 (A8) are subsequent regeneration cycles.

The repeating cycles of calcination/reconstruction processes gradually reduced the adsorption capacity of the HTC. The regeneration studies (see Table 2) show that the sorption capacity decreased by $\sim 30 \%$ after the three cycles; a decrease in capacity is seen in subsequent cycles though the HTC continues to adsorb silica. The change in the sorption capacity was influenced by the ability of calcined HTC to regenerate the layered crystal structure during the ion-exchange process.[38] XRD of HTC after each regeneration (Figure 8) shows a decreased in HTC crystallinity (peak intensities). [38] The decreased ability of calcined HTC to recrystallize to the original HTC structure after each regeneration cycle was commensurate with the decrease in silica adsorption capacity. 
Table 2. Percent silica removal from CCTW $\left(\mathrm{pH}=7.5,25{ }^{\circ} \mathrm{C}, 50 \mathrm{mg} / \mathrm{L} \mathrm{SiO}_{2}\right), 125 \mathrm{mg}$ calcined HTC during the regeneration process.

\begin{tabular}{ll}
\hline HTC Samples & $\begin{array}{l}\text { Removed Silica } \\
(\%)\end{array}$ \\
\hline Calcined HTC for first time (A2) & $97.5 \%$ \\
Calcined HTC for $2^{\text {nd }}$ times (A4) & $96.4 \%$ \\
Calcined HTC for $3^{\text {rd }}$ times (A6) & $95.3 \%$ \\
Calcined HTC for $4^{\text {th }}$ times (A8) & $65.4 \%$ \\
\hline
\end{tabular}

The structural affects of HTC regeneration can also be seen by FTIR. The peak at $\sim 1050 \mathrm{~cm}^{-1}$ (Figure 9) increases, which is attributed to an increase in the stretching mode of Si-O.[6] The intensity of this absorption peak gradually increased after each calcination and reconstruction cycle. The combination of the FTIR data with the XRD data (showing a decrease in crystallinity with regeneration) suggests that with regeneration the 2D layers of the HTC are broken apart, and bound interlayer $\mathrm{Si}-\mathrm{O}$ are allowed to stretch which is normally restricted in the interlayers of crystalline HTC.

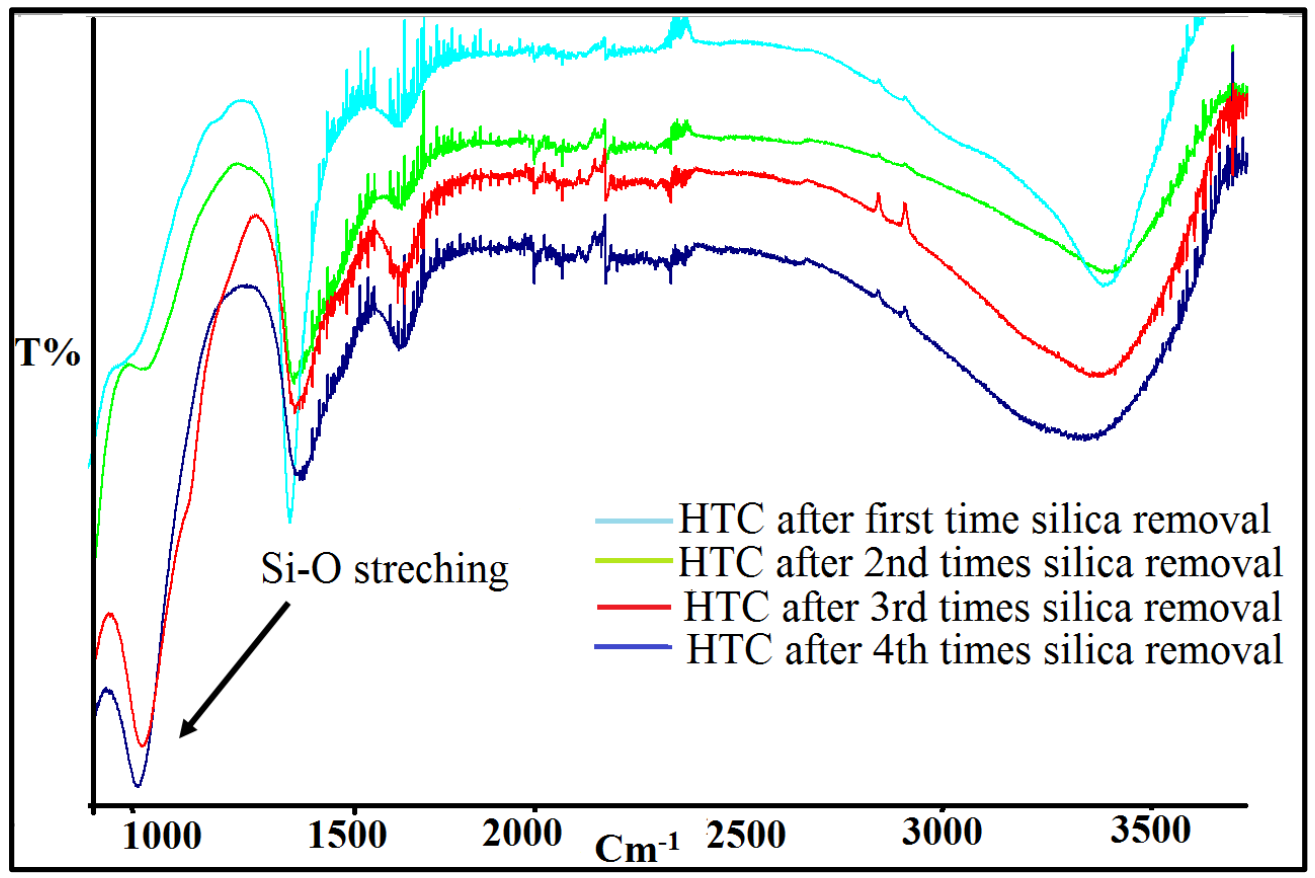

Figure 9. FTIR spectra of HTCs (after silica removal process) during multiple regeneration cycles. 


\subsection{Effect of varying HTC composition on silica removal}

The effect of HTC composition on silica removal from CCTW was investigated. ZnHTC was calcined in the air at $300{ }^{\circ} \mathrm{C}$ for $2 \mathrm{~h}$, as previously reported.[22] As shown in figure 10, using $125 \mathrm{mg}$ of $\mathrm{Zn}-\mathrm{HTC}$ resulted in only $84 \%$ silica removal, while using either 75 or $125 \mathrm{mg}$ of calcined HTC resulted in more than $95 \%$ silica removal. (see figure 10). Also, the average silica removal of $\mathrm{Zn}-\mathrm{HTC}$ is $41.3 \%$ after 4 regeneration cycles (see SI; Table 1). By contrast, the average silica removal for 4 regeneration cycles of HTC is $88.6 \%$ (see Table 2). Upon calcination of Zn-HTC a stable phase of spinel $\mathrm{ZnAl}_{2} \mathrm{O}_{4}$ is formed (see SI Figure 4). [22] This spinel is a dense phase and probably influence with silica adsorption. Overall, these results indicate that original HTC is a better silica removal material than Zn-HTC.

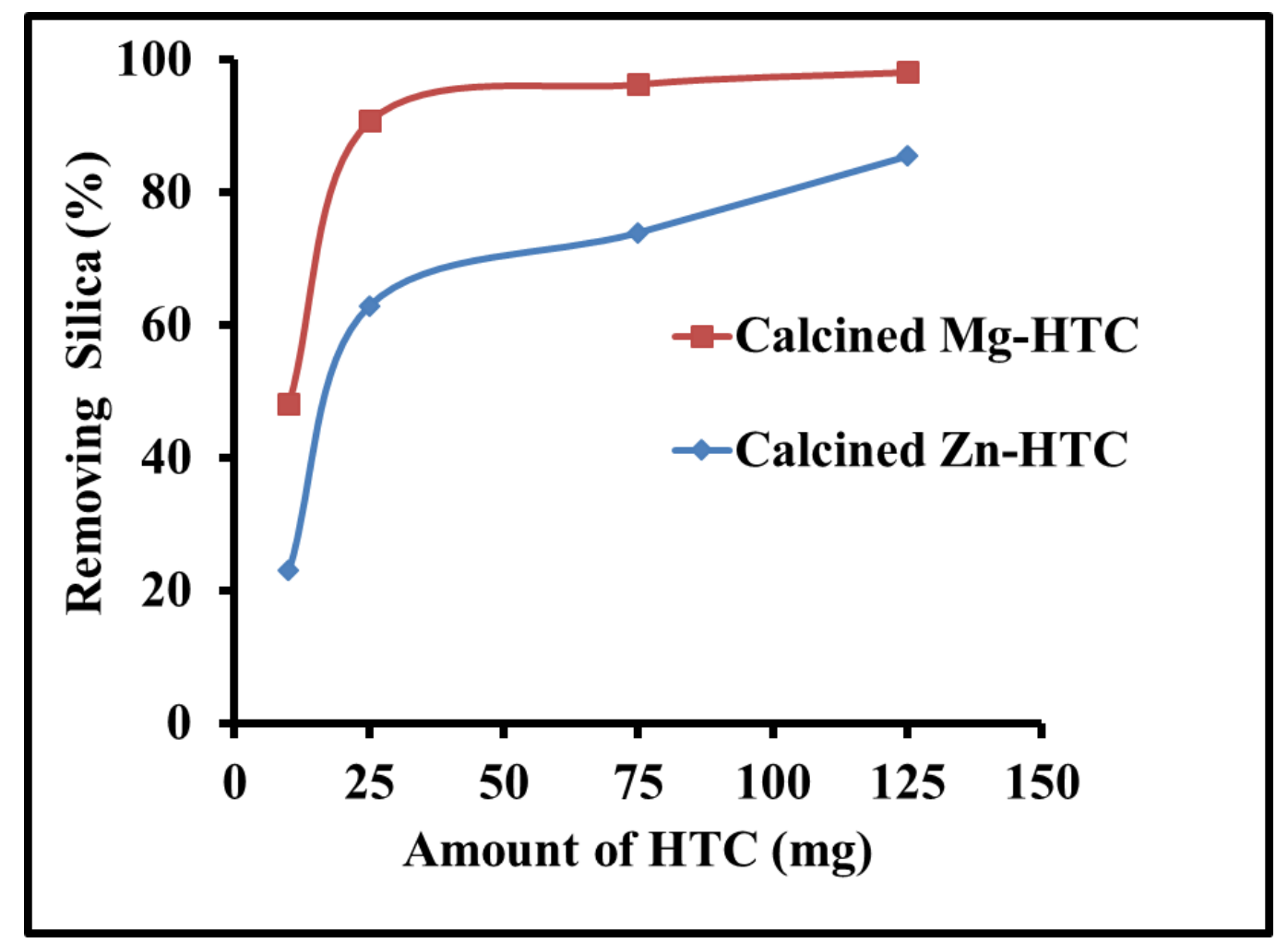

Figure 10. Silica removal from CCTW by calcined HTC (Mg-HTC) and Zn-HTC (pH = 7.0, 25 $\left.{ }^{\circ} \mathrm{C}, 50 \mathrm{mg} / \mathrm{L} \mathrm{SiO} 2\right)$. 


\subsection{Kinetics of silica removal by calcined HTC}

In order to further investigate the kinetics of the HTC as an ion-exchange material for silica removal, four different rate equation models were used to fit the experimental results; first order, second order, pseudo-first order and pseudo-second order models.

The silica adsorption kinetics were best represented by a Pseudo-second order equation, $\left[t / q_{t}=1 / k_{2}{ }^{l} q e^{2}+t / q_{e}\right]$, where $K_{2}{ }^{l}(\mathrm{~g} / \mathrm{mg} / \mathrm{min})$ is the Pseudo-second order rate constant.[39-41] The values of $t / q_{t}$ were plotted against given time ( $t$ ) as shown in Figure 11, the rate constant and regression coefficient $\left(\mathrm{R}^{2}\right)$ are given in Table 3. The regression coefficient value $\left(\mathrm{R}^{2}\right)$ of 0.99 indicated that this model provides an excellent fit to the experimental data of all four models for removing silica.

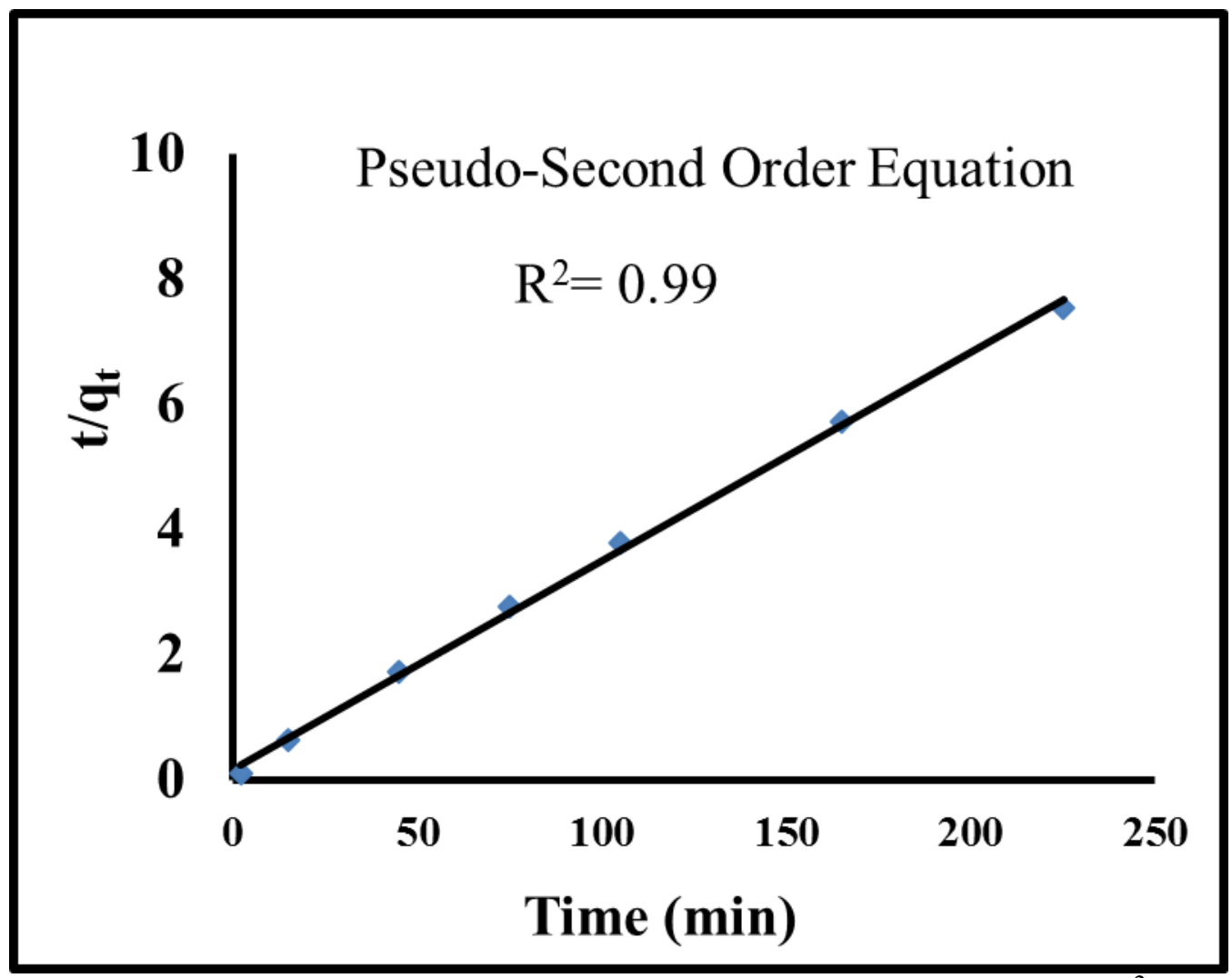

Figure 11. Silica removal by calcined HTC; pseudo-second order equation plot, $\mathrm{R}^{2}$ value $=0.99$.

Fitting this model implies that the rate of silica adsorption on the calcined HTC ionexchanged sites is proportional to the square of the number of unoccupied active sites.[39] Since 
the ion-exchange kinetics is largely controlled by the active sites of calcined HTC available for sorption, the initial fast rate of ion-exchange (Figure 4) is attribute to the availability of adsorption free sites especially on the surface of the calcined HTC.

Table 3. Kinetic rate parameters for silica removal by calcined HTC

\begin{tabular}{|c|c|}
\hline First Order & Second Order \\
\hline $\begin{array}{lr}\mathrm{K}_{1} & \mathrm{R}^{2} \\
0.0058 & 0.85\end{array}$ & $\begin{array}{cc}\mathrm{K}_{2} & \mathrm{R}^{2} \\
0.0006 & 0.97\end{array}$ \\
\hline Pseudo-first Order & Pseudo-second Order \\
\hline $\begin{array}{cc}\mathrm{K}_{1}{ }^{1} & \mathrm{R}^{2} \\
0.0126 & 0.96\end{array}$ & $\begin{array}{cc}\mathrm{K}_{2}{ }^{1} & \mathrm{R}^{2} \\
0.006 & 0.99\end{array}$ \\
\hline
\end{tabular}

\section{Conclusions}

Dissolved silica is ubiquitous in impaired waters, a fouling agent in desalination membranes, resistant to existing antiscalants, and difficult to remove from power plant feed waters, thereby inhibiting long term reuse of industrial water. Herein is presented a fast, energy efficient and low cost material for the removal of silica ions from industrial waters: the high selectivity anion-exchanger hydrotalcite $\left(\mathrm{Mg}_{6} \mathrm{Al}_{2}(\mathrm{OH})_{16}\left(\mathrm{CO}_{3}\right) \bullet\right.$ $4 \mathrm{H}_{2} \mathrm{O}, \mathrm{HTC}$ ) material. The results indicated that the calcined HTC removes $>90 \%$ silica from batch solutions as compared to uncalcined HTC. SPFT tests point to rapid adsorption of silicate and an overall uptake capacity of $\sim 45 \mathrm{mg} \mathrm{SiO}_{2} / \mathrm{g}$ HTC. Structure study indicates that the silica ions are exposed to a larger number of ion exchange sites on the calcined HTC. Composition studies with zinc analog HTC show decrease silica adsorption properties.

Materials characterization studies indicate that in the calcined HTC the silica anions have easy access to the oxide exchange sites. XRD and FTIR confirm both the recrystallization of the HTC when mixed with silica containing waters; SEM-EDS confirms the conclusion of the silica in the HTC. By utilizing the solubility of silica in water at varying pHs, and the selectivity of the HTC ion-exchange material, $>90 \%$ silicate anion removal is obtained from waters such as simulated CCTW and waters with 
competing ions such as $\mathrm{SO}_{4}{ }^{2-}$ and $\mathrm{Cl}^{-}$. Early stage research on regeneration shows that the HTC can be regenerated and reused multiple times.

The kinetics data demonstrate that the silica removal rate by calcined HTC is independent of starting $\mathrm{pH}$ of the waters. The pseudo-second order model high $\mathrm{R}^{2}$ value (0.99) fit indicates that the silica removal rate is proportional to square number of unoccupied sites on the calcined HTC. This kinetic model indicates that fast initial rate of silica removal is due to the availability of free adsorption sites on the calcined HTC.

Overall, this study proves that using the HTC as an ion-exchange material is an effective method for removal of silica from CCTW. Ongoing studies into technoeconomic modeling and scale-up analysis will help direct this research toward real world implementation. 


\section{Acknowledgements}

This work is supported by the Laboratory Directed Research and Development Program at Sandia National Laboratories. Sandia National Laboratories is a multi-mission laboratory managed and operated by Sandia Corporation, a wholly owned subsidiary of Lockheed Martin Corporation, for the U.S. DOE's NNSA under contract DE-AC0494AL85000. 


\section{References}

[1] V.K. Gupta, I. Ali, T.A. Saleh, A. Nayak, S. Agarwal, Chemical treatment technologies for waste-water recycling-an overview, RSC Advances, 2 (2012) 6380-6388.

[2] N. Abdel-Raouf, A.A. Al-Homaidan, I.B.M. Ibraheem, Microalgae and wastewater treatment, Saudi Journal of Biological Sciences, 19 (2012) 257-275.

[3] K. Averyt, J. Fisher, A. Huber-Lee, A. Lewis, J. Macknick, N. Madden, J. Rogers, and S. Tellinghuisen, Freshwater Use by U.S. Power Plants: Electricity's Thirst for a Precious Resource, The Union of Concerned Scientists' Energy and Water in a Warming World Initiative, (2011).

[4] Use of Degraded Water Sources as Cooling Water in Power Plants, Electric Power Research Institute (EPRI), (2003) Report 1005359.

[5] H.-H. Cheng, S.S. Chen, S.-R. Yang, In-line coagulation/ultrafiltration for silica removal from brackish water as RO membrane pretreatment, Separation and Purification Technology, 70 (2009) 112-117.

[6] I. Latour, R. Miranda, A. Blanco, Optimization of silica removal with magnesium chloride in papermaking effluents: mechanistic and kinetic studies, Environmental Science and Pollution Research, 23 (2015) 3707-3717.

[7] I. Latour, R. Miranda, A. Blanco, Silica removal from newsprint mill effluents with aluminum salts, Chemical Engineering Journal, 230 (2013) 522-531.

[8] D. Hermosilla, R. Ordóñez, L. Blanco, E. de la Fuente, Á. Blanco, pH and Particle Structure Effects on Silica Removal by Coagulation, Chemical Engineering \& Technology, 35 (2012) 1632-1640.

[9] Y. Liu, M. Tourbin, S. Lachaize, P. Guiraud, Silica Nanoparticle Separation from Water by Aggregation with AlCl3, Industrial \& Engineering Chemistry Research, 51 (2012) 1853-1863.

[10] D.L. Gallup, F. Sugiaman, V. Capuno, A. Manceau, Laboratory investigation of silica removal from geothermal brines to control silica scaling and produce usable silicates, Applied Geochemistry, 18 (2003) 1597-1612.

[11] S. Salvador Cob, C. Yeme, B. Hofs, E.R. Cornelissen, D. Vries, F.E. Genceli Güner, G.J. Witkamp, Towards zero liquid discharge in the presence of silica: Stable $98 \%$ recovery in nanofiltration and reverse osmosis, Separation and Purification Technology, 140 (2015) 23-31. [12] S.A. Nabi, M. Naushad, Studies of cation-exchange thermodynamics for alkaline earths and transition metal ions on a new crystalline cation-exchanger aluminium tungstate: Effect of the 
surfactant's concentration on distribution coefficients of metal ions, Colloids and Surfaces A: Physicochemical and Engineering Aspects, 293 (2007) 175-184.

[13] S.A. Nabi, M. Naushad, Synthesis, characterization and analytical applications of a new composite cation exchanger cellulose acetate- $\mathrm{Zr}(\mathrm{IV})$ molybdophosphate, Colloids and Surfaces A: Physicochemical and Engineering Aspects, 316 (2008) 217-225.

[14] S.A. Nabi, M. Naushad, Inamuddin, Synthesis and characterization of a new inorganic cation-exchanger- $\mathrm{Zr}(\mathrm{IV})$ tungstomolybdate: Analytical applications for metal content determination in real sample and synthetic mixture, Journal of Hazardous Materials, 142 (2007) 404-411.

[15] J.D. Pless, M.L.F. Philips, J.A. Voigt, D. Moore, M. Axness, J.L. Krumhansl, T.M. Nenoff, Desalination of Brackish Waters Using Ion-Exchange Media, Industrial \& Engineering Chemistry Research, 45 (2006) 4752-4756.

[16] A. Fahami, G.W. Beall, Structural and morphological characterization of $\mathrm{Mg}_{0.8} \mathrm{Al}_{0.2}(\mathrm{OH})_{2} \mathrm{Cl}_{0.2}$ hydrotalcite produced by mechanochemistry method, Journal of Solid State Chemistry, 233 (2016) 422-427.

[17] R.P. Bontchev, S. Liu, J.L. Krumhansl, J. Voigt, T.M. Nenoff, Synthesis, Characterization, and Ion Exchange Properties of Hydrotalcite $\mathrm{Mg}_{6} \mathrm{Al}_{2}(\mathrm{OH})_{16}(\mathrm{~A})_{\mathrm{x}}\left(\mathrm{A}^{\mathrm{c}}\right)_{2-\mathrm{x}} \cdot 4 \mathrm{H}_{2} \mathrm{O}\left(\mathrm{A}, \mathrm{A}^{`}=\mathrm{Cl}^{\circ}, \mathrm{Br}^{\circ}, \mathrm{I}^{`}\right.$, and $\mathrm{NO}_{3}^{-}, 2 \geq \mathrm{x} \geq 0$ ) Derivatives, Chemistry of Materials, 15 (2003) 3669-3675.

[18] D. Wan, H. Liu, R. Liu, J. Qu, S. Li, J. Zhang, Adsorption of nitrate and nitrite from aqueous solution onto calcined ( $\mathrm{Mg}-\mathrm{Al}$ ) hydrotalcite of different $\mathrm{Mg} / \mathrm{Al}$ ratio, Chemical Engineering Journal, 195-196 (2012) 241-247.

[19] http://energy.gov/under-secretary-science-and-energy/downloads/water-energy-nexuschallenges-and-opportunities

[20] D.G. Cantrell, L.J. Gillie, A.F. Lee, K. Wilson, Structure-reactivity correlations in MgAl hydrotalcite catalysts for biodiesel synthesis, Applied Catalysis A: General, 287 (2005) 183-190. [21] G.M. Lombardo, G.C. Pappalardo, F. Punzo, F. Costantino, U. Costantino, M. Sisani, A Novel Integrated X-ray Powder Diffraction (XRPD) and Molecular Dynamics (MD) Approach for Modelling Mixed-Metal ( $\mathrm{Zn}, \mathrm{Al}$ ) Layered Double Hydroxides (LDHs), European Journal of Inorganic Chemistry, 2005 (2005) 5026-5034. 
[22] X. Cheng, X. Huang, X. Wang, D. Sun, Influence of calcination on the adsorptive removal of phosphate by $\mathrm{Zn}-\mathrm{Al}$ layered double hydroxides from excess sludge liquor, Journal of Hazardous Materials, 177 (2010) 516-523.

[23] K.-H. Goh, T.-T. Lim, Z. Dong, Application of layered double hydroxides for removal of oxyanions: A review, Water Research, 42 (2008) 1343-1368.

[24] G. Fetter, A. Botello, V.H. Lara, P. Bosch, Detrital $\mathrm{Mg}(\mathrm{OH})_{2}$ and $\mathrm{Al}(\mathrm{OH})_{3}$ in Microwaved Hydrotalcites, Journal of Porous Materials, 8 (2001) 227-232.

[25] J.C.A.A. Roelofs, J.A. van Bokhoven, A.J. van Dillen, J.W. Geus, K.P. de Jong, The Thermal Decomposition of $\mathrm{Mg}-\mathrm{Al}$ Hydrotalcites: Effects of Interlayer Anions and Characteristics of the Final Structure, Chemistry - A European Journal, 8 (2002) 5571-5579.

[26] H. Wang, J. Chen, Y. Cai, J. Ji, L. Liu, H.H. Teng, Defluoridation of drinking water by $\mathrm{Mg} / \mathrm{Al}$ hydrotalcite-like compounds and their calcined products, Applied Clay Science, 35 (2007) 59-66.

[27] K.L. Erickson, T.E. Bostrom, R.L. Frost, A study of structural memory effects in synthetic hydrotalcites using environmental SEM, Materials Letters, 59 (2005) 226-229.

[28] L. Lv, Y. Wang, M. Wei, J. Cheng, Bromide ion removal from contaminated water by calcined and uncalcined $\mathrm{MgAl}-\mathrm{CO}_{3}$ layered double hydroxides, Journal of Hazardous Materials, 152 (2008) 1130-1137.

[29] Q. Tao, Y. Zhang, X. Zhang, P. Yuan, H. He, Synthesis and characterization of layered double hydroxides with a high aspect ratio, Journal of Solid State Chemistry, 179 (2006) 708715.

[30] V. Rives, Characterisation of layered double hydroxides and their decomposition products, Materials Chemistry and Physics, 75 (2002) 19-25.

[31] J.T. Kloprogge, L. Hickey, R.L. Frost, Synthesis and spectroscopic characterization of deuterated hydrotalcite, Journal of Materials Science Letters, 21 (2002) 603-605.

[32] T. Stanimirova, I. Vergilov, G. Kirov, N. Petrova, Thermal decomposition products of hydrotalcite-like compounds: low-temperature metaphases, Journal of Materials Science, 34 4153-4161.

[33] Q. Wang, D. O'Hare, Recent Advances in the Synthesis and Application of Layered Double Hydroxide (LDH) Nanosheets, Chemical Reviews, 112 (2012) 4124-4155. 
[34] J. He, M. Wei, B. Li, Y. Kang, D.G. Evans, X. Duan, Preparation of Layered Double Hydroxides, in: X. Duan, D.G. Evans (Eds.) Layered Double Hydroxides, Springer Berlin Heidelberg, Berlin, Heidelberg, 2006, pp. 89-119.

[35] N.A. Milne, T. O'Reilly, P. Sanciolo, E. Ostarcevic, M. Beighton, K. Taylor, M. Mullett, A.J. Tarquin, S.R. Gray, Chemistry of silica scale mitigation for RO desalination with particular reference to remote operations, Water Research, 65 (2014) 107-133.

[36] Y. Wang, H. Gao, Compositional and structural control on anion sorption capability of layered double hydroxides (LDHs), Journal of Colloid and Interface Science, 301 (2006) 19-26. [37] W. Ma, N. Zhao, G. Yang, L. Tian, R. Wang, Removal of fluoride ions from aqueous solution by the calcination product of $\mathrm{Mg}-\mathrm{Al}-\mathrm{Fe}$ hydrotalcite-like compound, Desalination, 268 (2011) 20-26.

[38] F. Teodorescu, A.M. Pălăduţă, O.D. Pavel, Memory effect of hydrotalcites and its impact on cyanoethylation reaction, Materials Research Bulletin, 48 (2013) 2055-2059.

[39] A.G.K.a.O.I.C. Dawodu Folasegun Anthony Application of kinetic rate equations on the removal of copper (II) ions by adsorption unto "Aloji" kaolinite clay mineral, International journal of multidisciplinary sciences and engineering 3(2012).

[40] A. El Nemr, A. El-Sikaily, A. Khaled, O. Abdelwahab, Removal of toxic chromium from aqueous solution, wastewater and saline water by marine red alga Pterocladia capillacea and its activated carbon, Arabian Journal of Chemistry, 8 (2015) 105-117.

[41] S. Nethaji, A. Sivasamy, A.B. Mandal, Preparation and characterization of corn cob activated carbon coated with nano-sized magnetite particles for the removal of $\mathrm{Cr}(\mathrm{VI})$, Bioresource Technology, 134 (2013) 94-100. 


\section{Graphical Abstract}

Use of hydrotalcite (HTC) as an ion exchange material is an effective method for removing dissolved silica from industrial and utility water supplies.

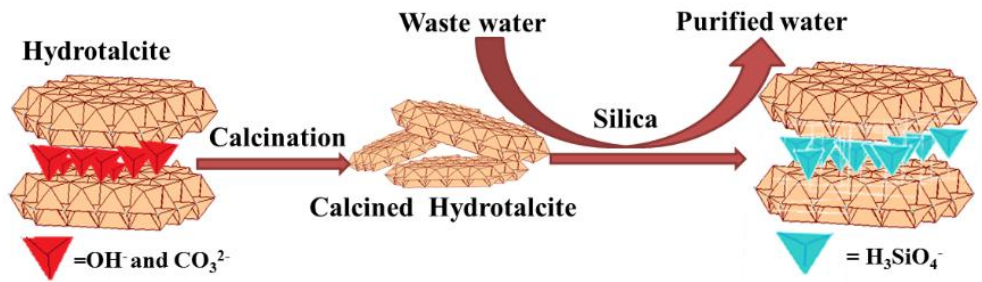

